The Jacobs

\section{Foundation}

Series on

\section{Adolescence}

TRANSTTIONS

FROM SCHOOL

TO WORK

Globalization,

Individualization,

and Patterns

of Diversity

Editedisy

NGRID SCHOON

RAINER K. SIIBEREISEN 


\title{
3 Is Stable Employment Becoming More Elusive for Young Men?
}

\author{
Mary Corcoran and Jordan Matsudaira
}

Stable employment is a key indicator of a man's successful transition from school to work. By their late twenties, men are expected to work on a regular basis. Erratic employment early in a man's labor-market career can permanently lower his lifetime earnings. Topel and Ward (1992) estimated that three quarters of men's lifetime wage growth occurs in their first ten years of work.

Scholars contend that in the United States, young men - particularly those with low levels of schooling and African American men - are increasingly becoming disconnected from employment (Besharov, 1999; Corcoran \& Matsudaira, 2005; Devereux, 2003; Edelman, Holzer, \& Offner, 2006; Freeman \& Holzer, 1986; Handel, 2003; Holzer, Offner, \& Sorenson, 2005; Juhn, 1992; Juhn \& Potter, 2006; Mincy, 2006; Wilson, 1987, 1996). Edelman et al. (2006, p. 18) estimated that in 1999, "just over a third of young black male high school dropouts are employed." Analysts are divided in their explanations for this phenomenon. Some researchers suggested that the changes are due to the development of new norms about the transition to adulthood that have encouraged young adults to be less seriously engaged in the labor market. In contrast, other researchers point to economic and structural factors that limit young adults' employment prospects.

In this chapter, we provide further documentation on the decline in stable employment among young men in the United States. We build on past research by showing how men's work trajectories in the twenty-one years between the ages of twenty and forty have changed across four birth cohorts using the 1967 to 2006 March Current Population Surveys (CPS). We then use the 1970 to 2001 waves of the Panel Study of Income Dynamics (PSID) to calculate and measure the long-term disconnection from work 
for six birth cohorts of men. Although the evidence presented is primarily descriptive, we comment on whether the data seem to support explanations involving culture differences between cohorts or whether economic factors seem more relevant.

\section{Background}

Since the late 1970s, there have been several striking changes in the structure of jobs in the United States. The number of jobs in the manufacturing sector has declined, and the number of jobs in the service and the "knowledge" sectors has increased (Andersson, Holzer, \& Lane, 2006; Blank, 1998; Bound \& Holzer, 1993; Danziger \& Gottschalk, 1995; Juhn, 1992; Levy \& Murnane, 1992; Royalty, 1998; Wilson, 1996). One explanation offered for these changes is globalization: firms have increasingly moved production facilities overseas to reduce labor costs. Another potential explanation is that technological changes, particularly computers, have eliminated some low-skill jobs, reduced the skill requirements for other jobs, and increased the number of jobs with high-skill requirements (Autor, Levy; \& Murnane, 2002; Bound \& Freeman, 1992; Juhn, Murphy, \& Pierce, 1997; Morris \& Western, 1999; Powell \& Snellman, 2004). This has led to increases in the demand for and in returns to cognitive skills, technical skills, and communication/management skills and has led to decreases in both the pay and the number of jobs available to people with low to moderate skills (Bound \& Johnson, 1992; Juhn, 1992; Juhn \& Potter, 2006; Katz \& Murphy, 1992). For instance, between 1967 and 1987, the ratio of employment to population among male high school dropouts dropped from 0.89 to 0.75 , and the real wages of men in the bottom decile of the wage distribution dropped by 6 percent (Juhn, 1992).

Decreases in union membership rates, increases in contingent jobs, and high rates of immigration may have further weakened the prospects of lowskilled workers. According to Hollister (2004), the percentage of workers who are members of unions has been declining steadily since the 1960s. A primary function of a union is to bargain with management for job security, benefits, and wages. As union membership declines, low- and moderateskilled workers may be less protected against job losses (Bound \& Freeman, 1992; Hollister, 2004).

Contingent work allows employers to respond to labor-market fluctuations by hiring workers when demand is high and letting those workers go when demand declines (Autor et al., 2002; Blank, 1998), which increases employer flexibility but also can contribute to job instability. Some scholars contend that another way in which contingent work may contribute to job instability is by trapping workers in a "revolving door" between "temp" jobs, nonwork, and dead-end jobs, thus inhibiting their abilities to establish continuous work records (Autor \& Houseman, 2006).

The influx of low-skilled immigrants has increased the pool of workers competing for low-skilled jobs. Since the 1965 U.S. Immigration and Nationality Act was fully enforced starting in 1969, the numbers of Hispanic and Asian immigrants with low levels of schooling entering the United States have risen (Lobo \& Salvo, 1998). Some analysts assert that lowskilled immigrants, both legal and illegal, crowd out native-born workers with low skills and that employers may view such low-skilled immigrants as "less trouble" or "more accommodating" than low-skilled native-born workers.

Wilson (1996) contended that although the job opportunities of all low-skilled workers have declined due to globalization, deindustrialization, technological upgrading, decreases in union coverage, and immigration, the declines were largest for minority males residing in predominantly poor inner-city neighborhoods. Several studies have documented that decreases in work and increases in nonwork are disproportionately high for black male high school dropouts (Bound \& Holzer, 1993; Edelman et al., 2006; Holzer \& Offner, 2004; Holzer, Offner, \& Sorenson, 2005; Juhn, 1992).

At the same time that labor-market options were declining for lowskilled workers, policies such as freezes of the minimum wage, mandatory sentencing laws, and mandatory child support also may have reduced lowskilled men's ability to get jobs and the economic returns to low-skilled work. The minimum wage was unchanged during the 1980s and was not increased from 1997, thus sharply eroding its real value and real wages in low-wage jobs.

Mandatory sentencing laws have increased the percentage of low-skilled men with criminal records (Edelman et al., 2006; Grogger, 1998; Holzer, Offner, \& Sorenson, 2005; Pattillo, Weiman, \& Western, 2006). According to Western et al. (2006), the federal and state incarceration rate increased from 93 to 470 per 100,000 between 1972 and 2001. Western et al. (2006) estimated that in 1994, the cumulative risk of having been imprisoned by age thirty to thirty-four was 18 percent for black male high school graduates and 59 percent for black male high school dropouts. Jail time interrupts young men's work and schooling, and a criminal record can be a barrier to employment (Harding, 2003; Holzer et al., 2005; Holzer, Raphael, \& Stoll, 2006; Pager, 2003; Western, 2006). 
Wage-garnishing due to mandatory child support reduces low-skilled men's disposable income from work and thus reduces their incentive to work (Edelman et al., 2006; Freeman \& Waldfogel, 1998, 2001; Holzer, Offner, \& Sorenson, 2005). Federal law allows states to garnish up to 65 percent of wages for delinquent child support (Holzer et al., 2005). Childsupport orders typically constitute 20 to 30 percent of a noncustodial father's income (Holzer et al., 2005).

Past researchers examined changes in men's connections to the labor market by documenting the extent to which the employment rates of men in a given age range vary over time. Thus, Juhn (1992) showed that the employment rate of men aged sixteen to fifty-four dropped from 0.93 to 0.87 between 1967 and 1987. Similarly, Holzer et al. (2005) examined the employment rates for two groups of men - those aged eighteen to twentyfour and those aged twenty-five to thirty-four for each year between 1979 and 2000 and showed that employment rates declined sharply for black men and modestly for white men between 1979 and 1993. Employment rates for both black and white men in these age groups rose between 1993 and 1999; however, employment rates for black men were lower in 1999 than in 1979. The employment rate of black men aged eighteen to twenty-four was 61.5 percent in 1979 and 51.3 percent in 1999; the employment rate of black men aged twenty-five to thirty-four was 81.3 percent in 1979 and 74.2 percent in 1999.

In what follows, we build on the literature discussed previously by investigating three sets of questions:

1. What do men's patterns of work activity look like between the ages of twenty and forty as they transition from school to work and establish careers? By what age are most men working on a regular basis?

2. Have patterns of work activity during these age ranges changed across different birth cohorts of men? Did men's work patterns become more erratic across cohorts? Did it take longer for men to achieve stable employment? Did larger percentages of men fail to reach stable employment? Were men who turned twenty in the late 1970s more likely to be disconnected from work than men who turned twenty in the late 1960s? Did the proportion of economically inactive men drop much during and after the 1993-1999 economic expansion?

3. What proportion of men still has not achieved stable employment by their late twenties? What is the incidence of long-term nonwork among men during the three years from age twenty-eight to thirty? How has long-term disconnection from work changed over time?

\section{CPS Sample and Definitions}

We first used the 1967 to 2006 March CPS surveys to construct a synthetic picture of men's employment activities for each year between the ages of twenty and forty as they move from school to work. We did this for four birth cohorts of white men and four birth cohorts of black men born in 1947-1949, 1957-1959, 1967-1969, and 1977-1979. To understand how we did this, consider men born in 1947. These men were twenty years old in 1967 , twenty-one years old in 1968, and forty years old in 1987. For each age between twenty and forty, we estimated the work activities of men born in 1947 using the relevant year of the March CPS; that is, we used the 1967 March CPS to calculate work activities at age twenty, the 1968 March CPS to calculate at age twenty-one, and the 1987 March CPS to calculate at age forty. Thus, for men born from 1947 to 1949, we used the 1967 to 1989 March CPS surveys to examine work activities at ages twenty to forty. For men born from 1957 to 1959, we used the 1977 to 1999 March CPS surveys to calculate work activities at age twenty to forty. For men born from 1967 to 1969 , we used the 1987 to 2006 surveys to calculate work activities at age twenty to thirty-seven. For men born from 1977 to 1979, we used the 1997 to 2006 March CPS surveys to calculate work activities at age twenty to twenty-seven.

The March CPS asks respondents about their employment status in the week prior to the interview and about weeks worked during the past calendar year. We constructed two measures of men's connections to work with the CPS data. The first describes men's work activities in the week prior to the interview. We categorized men into one of four mutually exclusive activities: (1) worked last week; (2) was in school and not in the labor force; (3) was unemployed but in the labor force last week; and (4) was neither in the labor force nor in school last week. The CPS does not ask respondents twenty-five years and older about school attendance; therefore, no men were assigned to the second category after age twenty-four. The fourth category provides an indicator of disconnection from work. Men ages twenty to twenty-five in this category are not working, not looking for work, and not in school. Men twenty-five and older in this category are not working and not looking for work, although a small fraction of them may be in school.

The second measure of connection to work is a dummy variable indicating men's employment during the past calendar year. This variable is assigned a value of 1 if the respondent worked in at least one week in the past calendar year and a value of zero if the respondent did not work at all in the past year. 


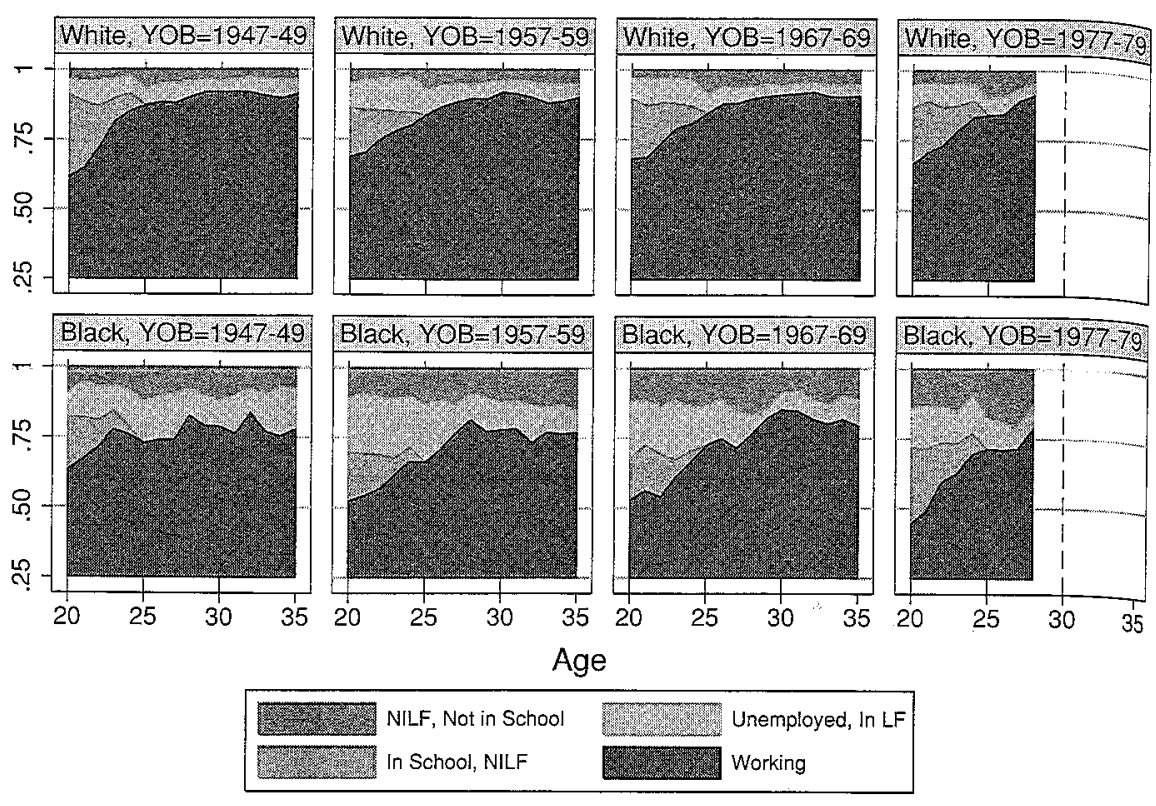

Figure 3.1. Men's Major Activity in Week Prior to March CPS Interview: All Men Ages 20 to 40 . Source: Authors' tabulations of 1962 to 2006 March Current Population Survey.

\section{CPS Results}

We began by constructing figures depicting changes during the ages from twenty to thirty-five in the fraction of men in each of the four activities described previously for four different year-of-birth cohorts using the CPS data on employment status in the week prior to the interview. Figure 3.1 reports results for the full sample of men; Figure 3.2 reports results for men with twelve or fewer years of schooling. There are eight panels in each figure: four for white men and four for black men in each birth cohort. The panels show how men's mix of labor-market activities changes from age twenty to age thirty-five as a race-birth cohort of men moves from school to employment. Comparisons of the panels for black and white men in the same birth cohort provide information on within-cohort black-white differences in men's transitions from school to work. Comparisons of work activities across different birth cohorts provide information about whether men become less connected to work over time.

The timing of men's school-to-work trajectories from age twenty to thirty-five is similar in each race-birth cohort in both Figures 3.1 and 3.2. Because changes are most pronounced for men with twelve or fewer years of

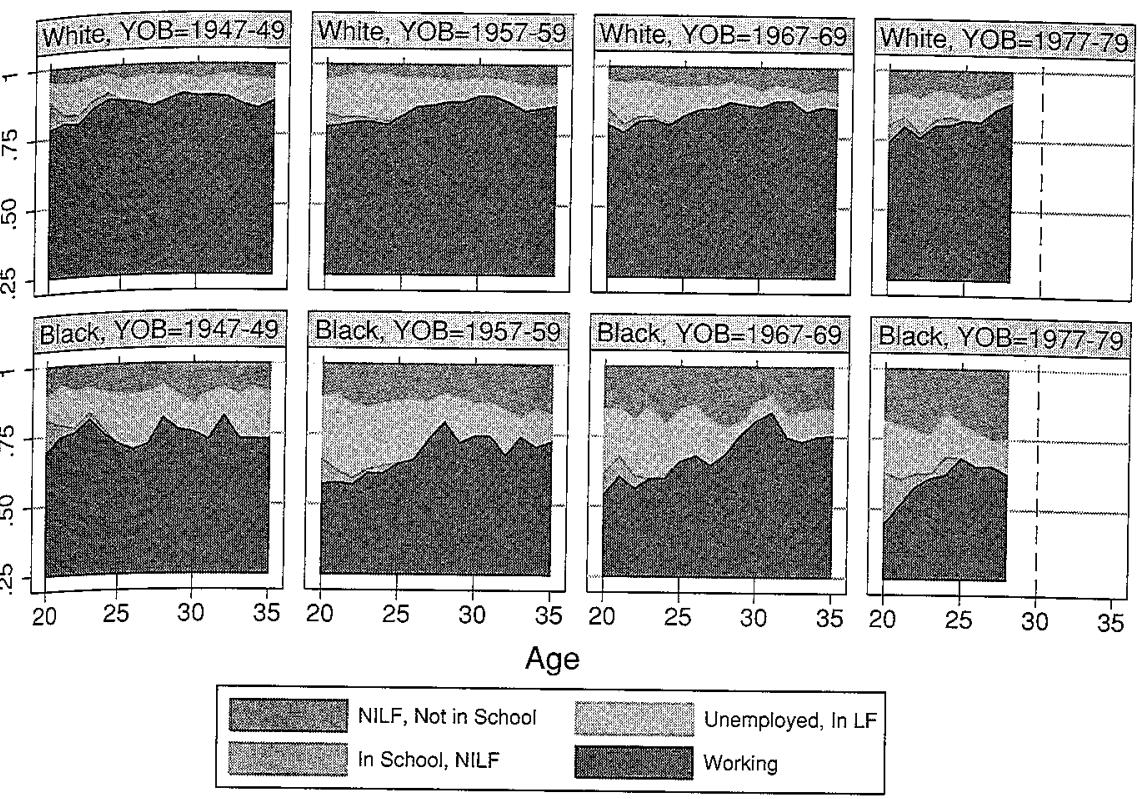

Figure 3.2. Men's Major Activity in Week Prior to March CPS Interview: Men Ages 20 to 40 with a High School Degree or Less. Source: Authors' tabulations of 1962 to 2006 March Current Population Survey.

schooling, we focus on the panels in Figure 3.2 in the discussion of results. In each cohort, the proportion of men not working and in school declines sharply in the early twenties and the proportion of men working rises sharply during the same age range. Men's employment rises more slowly during their twenties and stabilizes by the late twenties. The school-to-work transition takes a while and, after the late twenties, there is no consistent pattern of increases in the proportions of men who worked in the previous week.

Although the general timing of school-to-work trajectories is similar across the eight race-birth cohorts of men with twelve or fewer years of schooling, patterns of work do change across cohorts. One change is that men's work trajectories in the early years after leaving school are more erratic in the later birth cohorts. Men in the last three birth cohorts (i.e., 1957-1959, 1967-1969, and 1977-1979) are less likely to work and are more likely to be disconnected from school and work (i.e., out of the labor force and not in school) from age twenty to twenty-seven than men in the 19471949 birth cohort. For instance, as depicted in Table 3.1, in the later two birth cohorts, between 7.5 and 10.5 percent of white men and between 15 and 20 percent of black men with twelve or fewer years of schooling were 
out of the labor force at age twenty-five. A second change is that more men in later cohorts are still disconnected from work from age twenty-eight to thirty-five. Men born in the late 1950s and late 1960s are more likely than those born in the late 1940s to be neither working nor looking for work at ages twenty-eight to thirty-five. These changes are modest for white men but striking for black men. Only 10.3 percent of black men with twelve or fewer years of schooling who were born in the late 1940s cohort were out of the labor force at age thirty-five. In contrast, almost 17.9 and 15.3 percent of black men with twelve or fewer years of schooling in the late 1950s and late 1960 s birth cohort, respectively, were out of the labor force at age thirty-five.

Black-white differences in the work activities of men with twelve or fewer years of schooling are sizeable in each birth cohort. At each age in each birth cohort, black men are less likely to be working, more likely to be unemployed, and more likely to be economically inactive (i.e., not working, not looking for work, and not in school) than white men. Black-white differences in the proportions of men who are employed and men who are out of the labor force are larger in the last three birth cohorts than in the late 1940s birth cohort. Black-white differences in the proportion of men with twelve or fewer years of schooling who are out of the labor force at age twenty-eight to thirty-five are somewhat smaller for men born in the late 1960 s than for men born in the late 1950s, but the differences are still significant.

The panels in Figures 3.1 and 3.2 show men's labor-force status in the week prior to the March CPS interview for each year between the ages of eighteen and thirty-five for eight race-birth cohorts. We next examined whether men worked in at least one week of the calendar year prior to their March CPS interviews. We calculated this measure for each age from twenty to forty for men in each of the eight race-birth cohorts. These measures are plotted in Figures 3.3 and 3.4 Each figure includes two sets of graphs: one set for the four birth cohorts of white men and one set for the four birth cohorts of black men. Figure 3.3 reports results for all men; Figure 3.4 reports results for men with twelve or fewer years of schooling.

The graphs in Figures 3.3 and 3.4 tell much the same story about the timing of school-to-work transitions as Figures 3.1 and 3.2 Because a year of nonwork is more prevalent among men with twelve or fewer years of schooling than among men in the general population, we primarily discuss the findings presented in Figure 3.4. In all eight race-birth cohorts, the proportion of men who worked in at least one week during the past year rises rapidly in the early twenties, increases more slowly until the late twenties, and then levels off thereafter. Until the mid-twenties, substantial minorities 


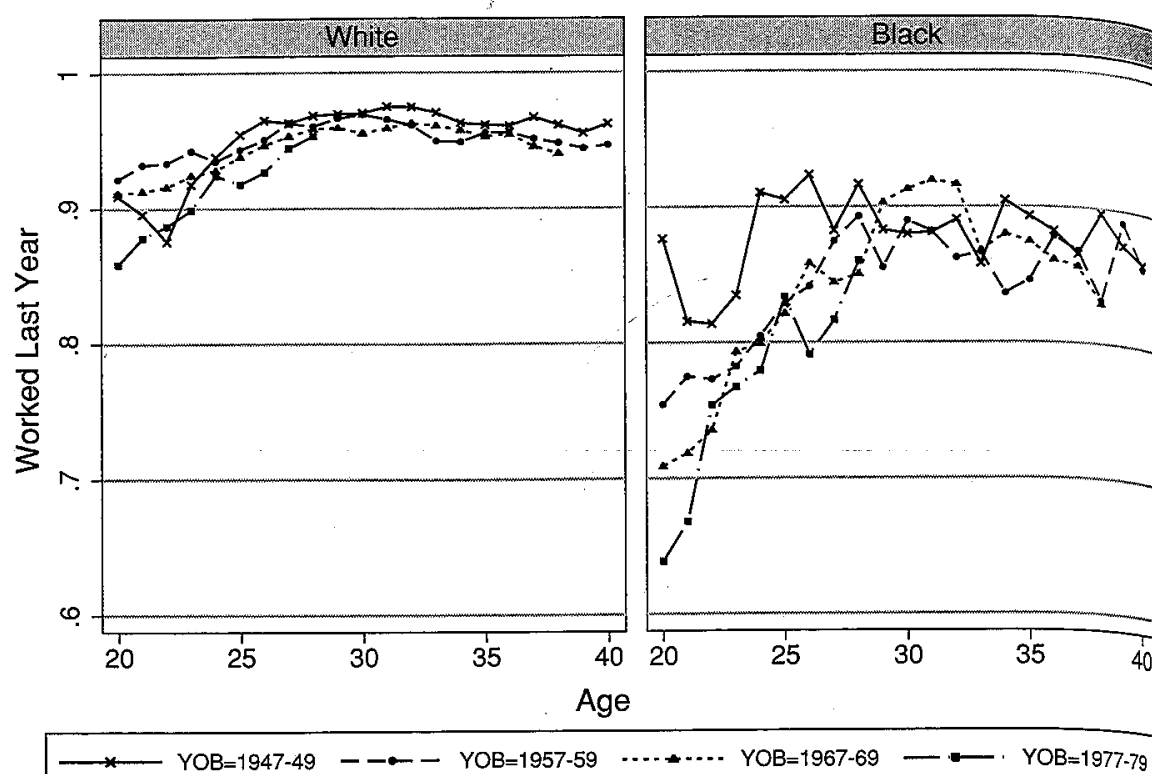

Figure 3.3. Fraction of Men Working at Least One Week Last Year by Birth Cohort and Race: Ages 20 to 40. Source: Authors' tabulations of 1962 to 2006 March Current Population Survey.

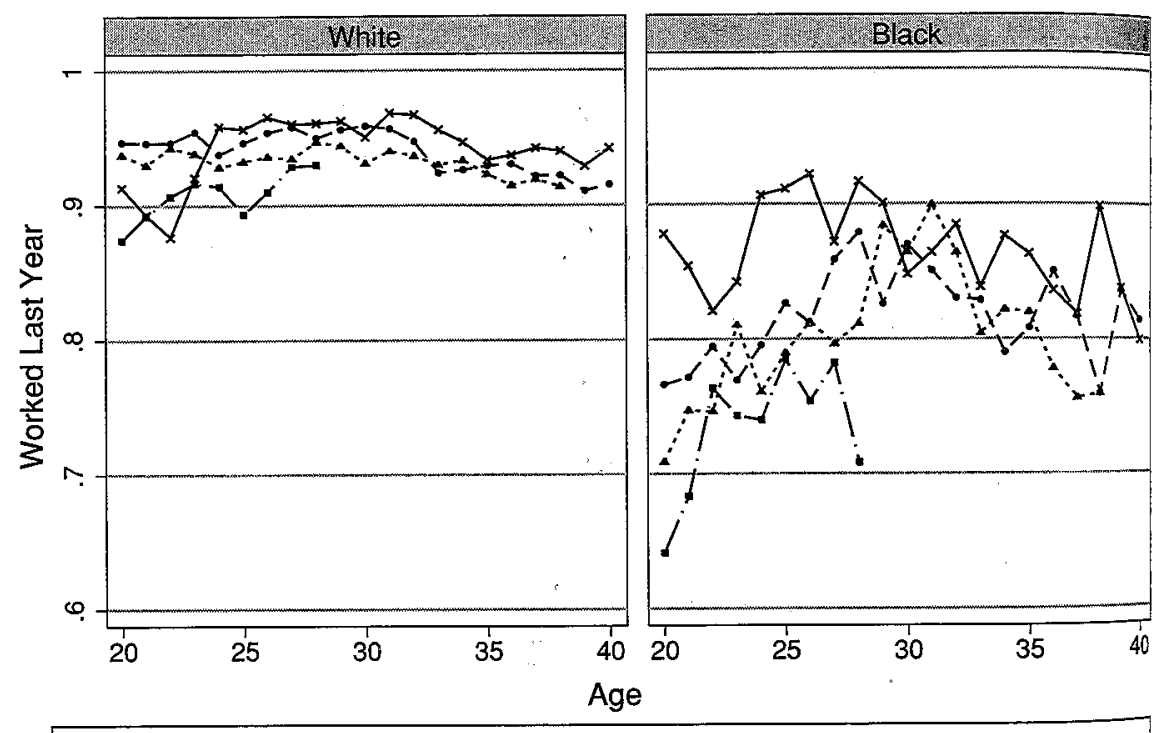

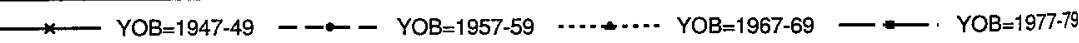

Figure 3.4. Fraction of Men with High School Degree or Less Working at Least One Week Last Year by Birth Cohort and Race: Ages 20 to 40. Source: Authors' tabulations of 1962 to 2006 March Current Population Survey.
Table 3.2. Fraction of Men with High School Degree or Less Reporting Any Work in Previous Year by Year of Birth Cohort and Age

\begin{tabular}{|c|c|c|c|c|c|c|}
\hline $\begin{array}{l}\text { Year of Birth } \\
\text { Cohort/Age }\end{array}$ & 20 & 25 & 30 & 35 & 40 & $\begin{array}{l}\text { Averag } \\
\mathrm{N}\end{array}$ \\
\hline & \multicolumn{6}{|c|}{ White Men } \\
\hline $\mathrm{YOB}=1942-44$ & 0.843 & 0.981 & 0.976 & 0.958 & 0.927 & 1,229 \\
\hline $\mathrm{YOB}=1947-49$ & 0.913 & 0.957 & 0.951 & 0.934 & 0.942 & 1,229 \\
\hline $\mathrm{YOB}=1952-54$ & 0.935 & 0.955 & 0.952 & 0.945 & 0.926 & 1,433 \\
\hline $\mathrm{YOB}=1957-59$ & 0.947 & 0.946 & 0.959 & 0.929 & 0.915 & 1,495 \\
\hline $\mathrm{YOB}=1962-64$ & 0.893 & 0.957 & 0.935 & 0.917 & 0.909 & 1,223 \\
\hline $\mathrm{YOB}=1967-69$ & 0.938 & 0.933 & 0.931 & 0.923 & & 856 \\
\hline $\mathrm{YOB}=1972-74$ & 0.887 & 0.933 & 0.918 & & & 667 \\
\hline \multirow[t]{2}{*}{ YOB $=1977-79$} & 0.874 & 0.893 & & & & 683 \\
\hline & \multicolumn{6}{|c|}{ Black Men } \\
\hline$Y O B=1942-44$ & 0.778 & 0.969 & 0.922 & 0.923 & 0.850 & 154 \\
\hline $\mathrm{YOB}=1947-49$ & 0.878 & 0.911 & 0.848 & 0.863 & 0.799 & 179 \\
\hline $\mathrm{YOB}=1952-54$ & 0.854 & 0.867 & 0.859 & 0.853 & 0.801 & 194 \\
\hline$Y O B=1957-59$ & $\circ 0.766$ & 0.826 & 0.870 & 0.808 & 0.814 & 197 \\
\hline $\mathrm{YOB}=1962-64$ & 0.658 & 0.826 & 0.791 & 0.750 & 0.778 & 193 \\
\hline $\mathrm{YOB}=1967-69$ & 0.709 & 0.789 & 0.864 & 0.820 & & 151 \\
\hline $\mathrm{YOB}=1972-74$ & 0.617 & 0.775 & 0.751 & & & 128 \\
\hline $\mathrm{YOB}=1977-79$ & 0.642 & 0.785 & & & & 161 \\
\hline
\end{tabular}

Source: Authors' tabulations of 1962 to 2006 March Current Population Survey

of black and white men with twelve or fewer years of schooling experience a full year of nonwork as they leave school and enter the work world.

Figure 3.4 shows the same cross-cohort changes in black men's connections to work as Figure 3.2. At most ages between twenty and forty, black men with twelve or fewer years of schooling who were born in the last three birth cohorts are more likely than those born from 1947 to 1949 to have not worked at all in the prior year. For instance, at age thirty-eight, about 22 to 24 percent of black male high school graduates and dropouts born in the late 1950s and 1960s did not work at all in the previous year.

Race gaps in disconnections from work are large among men with twelve or fewer years of schooling. In virtually every year between age twenty and forty, black men are more likely than white men to report a year of nonwork. For each birth cohort, the graphs that depict men's work trajectories rise smoothly with age for white men but are less smooth for black men. By the time men reach their late twenties, a year of nonwork is uncommon among white men but less so among black men. As shown in Table 3.2, in each year between the ages of thirty and forty, roughly 3 to 8 percent of white men report having not worked at all in the past year. By contrast, in each 


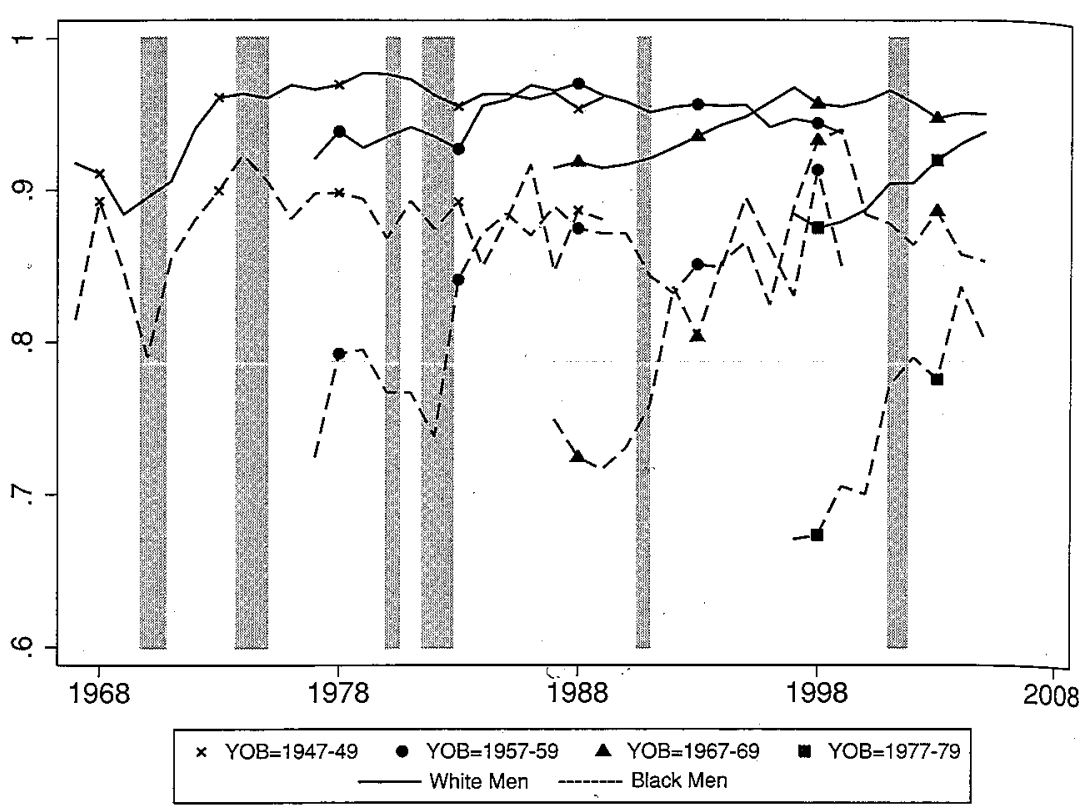

Figure 3.5. Fraction of Men Working at Least One Week Last Year by Birth Cohor and Race: 1968 to 2006. Source: Authors' tabulations of 1962 to 2006 March Current Population Survey. Shaded areas represent NBER peak-to-trough recessionary periods.

year between the same ages, roughly 8 to 25 percent of black men report having not worked at all in the previous year. Black-white gaps in men's connections to work widen between the 1950s and 1940s birth cohorts and remain significant in the 1960 s and 1970 s cohorts.

To show how employment varies with economic upturns and downturns, Figures 3.5 and 3.6 plot the age twenty to forty work trajectories of the eight race-birth cohorts of men by calendar years instead of by age. Figure 3.5 reports results for men in the general population and Figure 3.6 reports results for men with twelve or fewer years of schooling. Because men with less schooling are more affected by economic changes, we focus our discussion on Figure 3.6.

There are three patterns in the graphs in Figure 3.6. First, as expected, black men's employment responds more to economic cycles than does that of white men. Second, even at the height of the 1990s expansion, many black men in their late twenties and thirties did not work at all in the given year. For example, one in ten black men with twelve or fewer years of schooling from age twenty-nine to thirty-one (i.e., the 1967-1969 birth cohort) did not work a single week in 1998. Third, black men in the late 1970s

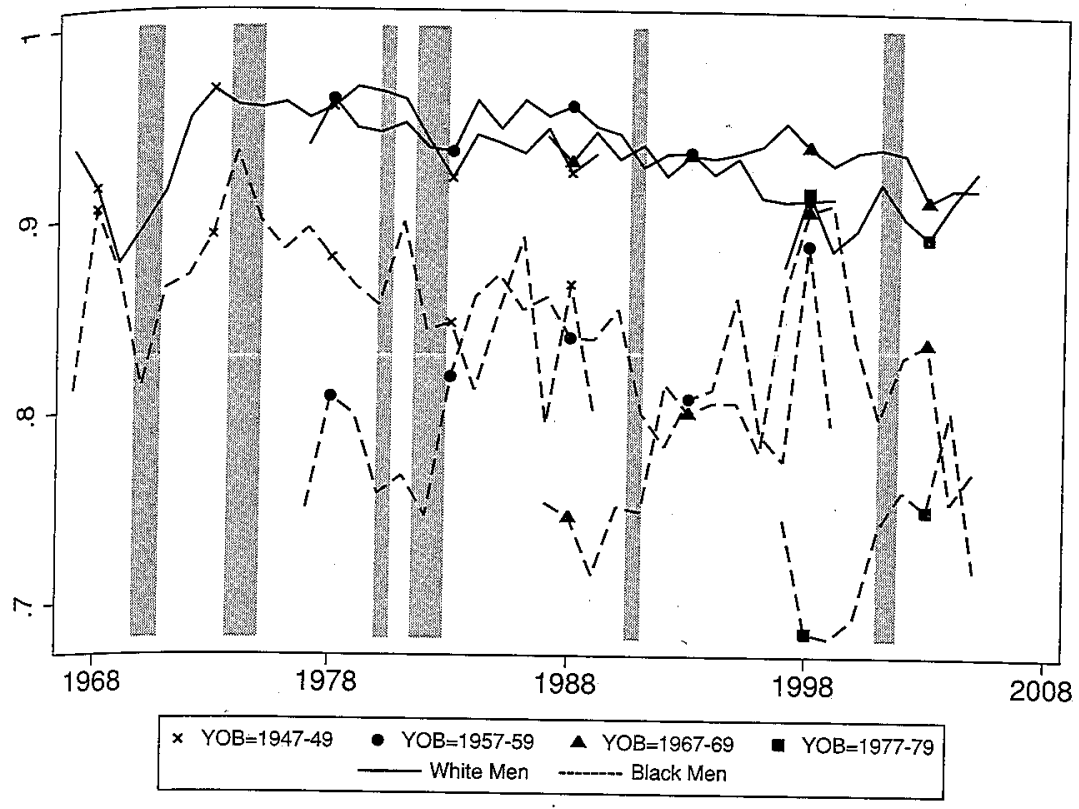

Figure 3.6. Fraction of Men with High School Degree or Less Working at Least One Week Last Year by Birth Cohort and Race: 1968 to 2006. Source: Authors' tabulations of 1962 to 2006 March Current Population Survey. Shaded areas represent NBER peak-to-trough recessionary periods.

birth cohort have high rates of disconnection from work. Almost one in four black men with twelve or fewer years of schooling between the ages of twenty-seven and twenty-nine in 2006 did not work a single week in 2005.

The patterns in Figures 3.5 and 3.6 may also shed light on the debate about why young men appear to be less attached to the labor force. Many sociological explanations have focused on how later cohorts may be exceptional in their norms or attitudes toward work. In Figure 3.6, however, we see that the decline in employment is not only a cohort-specific phenomenon; for both white and black men, employment between the ages of twenty and forty is declining within cohorts as well. For example, it is true that twenty- or twenty-five-year-old black men born in 1967 were less likely to be working at that age than men born ten years earlier in 1957. However, employment declined for the 1957 birth cohort between the ages of twentyfive and thirty-five as well. Although this does not refute the importance of new attitudes about adulthood in explaining changes in employment, it does suggest that young men do not uniquely experience the decline in 
employment. In other words, the data do not require explanations based on the exceptionalism of younger cohorts.

\section{PSID Sample and Definition of Nonwork}

The CPS data allowed us to measure men's disconnections from work during a week and during a year. We used the PSID to construct a measure of men's disconnections from work during three years: the number of weeks of nonwork between the ages of twenty-eight and thirty. We chose this age range because the CPS analyses suggested that men's employment rates during the past week and past year level off by their late twenties. Using the 1970 to 2001 waves of the PSID, we examined men's weeks of nonwork during the three years between the ages of twenty-eight and thirty for men in six five-year birth cohorts: 1941-1945, 1946-1950, 1951-1955, 1956-1960, 1961-1965, and 1966-1970. As in the CPS analyses, we constructed birth cohorts separately for white and black men for a total of twelve race-birth cohorts. Because the PSID interviews a head of household about his weeks worked, weeks on strike, and weeks on sick leave in the prior calendar year, our samples included white and black men in those cohorts who were a head of household at age twenty-nine to thirty-one.

We constructed our measure of nonwork from age twenty-eight to thirty as the sum of weeks worked subtracted from 156 . We experimented with an alternative definition that counted weeks on sick leave, paid vacation, and on strike as time spent working but found few differences across the race and cohort comparisons. We used the measure based only on weeks of work because the latter measure was available for fewer years during the period. The nonwork measure can range from zero for men who were working every week during the three-year period to 156 for men who reported no weeks worked during the entire three-year period.

\section{The PSID Results}

Table 3.3 reports the distributions of weeks of nonwork for the twelve racebirth cohorts of men. In each cohort, there was considerable variation in the total weeks of nonwork that men accumulated between the ages of twenty-eight and thirty, and this variation was greater for blacks than for whites. Many men worked steadily between the ages of twenty-eight and thirty. In each cohort, more than 75 percent of white men and more than 49 percent of black men accumulated fewer than twenty-six weeks of nonwork between the ages of twenty-eight and thirty. However, in each cohort, a small minority of white men and a much larger minority of black men
Table 3.3. Distribution of Total Weeks of Nonwork: Ages $28-30$ by Year of Birth and Race

\begin{tabular}{cllcccc}
\hline YOB & 0-12 Weeks & 13-25 Weeks & 26-52 Weeks & 1-2 Years & $>$ 2 Years & \# Obs \\
\hline & & \multicolumn{5}{c}{ White Men } \\
$1941-45$ & 64.19 & 20.70 & 8.26 & 6.29 & 0.55 & 299 \\
$1946-50$ & 56.41 & 20.25 & 13.93 & 7.84 & 1.58 & 503 \\
$1951-55$ & 50.15 & 25.41 & 14.89 & 5.78 & 3.77 & 540 \\
$1956-60$ & 63.74 & 17.08 & 12.10 & 5.56 & 1.53 & 539 \\
$1961-65$ & 61.41 & 20.23 & 10.89 & 5.22 & 2.26 & 453 \\
$1966-70$ & 77.36 & 11.49 & 5.98 & 4.05 & 1.12 & 325 \\
& & & & & & \\
$1941-45$ & 50.42 & 20.10 & 20.21 & 4.01 & 5.27 & 102 \\
$1946-50$ & 46.36 & 26.30 & 16.11 & 5.59 & 5.64 & 206 \\
$1951-55$ & 35.01 & 14.67 & 22.20 & 19.92 & 8.21 & 302 \\
$1956-60$ & 37.76 & 25.37 & 9.64 & 19.61 & 7.62 & 285 \\
$1961-65$ & 57.68 & 9.08 & 10.11 & 12.63 & 10.50 & 226 \\
$1966-70$ & 69.43 & 6.53 & 5.33 & 15.12 & 3.59 & 109
\end{tabular}

Source: Authors' tabulations of Panel Study of Income Dynamics.

experienced a year or more of nonwork during the three years between the ages of twenty-eight and thirty.

Changes in the distribution of nonwork across the birth cohorts are small for white men but large for black men. Black men born in the 1950s (i.e., 1951-1960) are less likely to work steadily and more likely to accumulate substantial nonwork than black men born in the 1940s (i.e., 1941-1950). About 70 to 72 percent of black men born in the 1940s but only 50 to 63 percent of black men born in the 1950s accumulated fewer than twenty-six weeks of nonwork from age twenty-eight to thirty. About 9 to 11 percent of black men born in the 1940s but 28 percent of black men born in the 1950s accumulated a year or more of nonwork from age twenty-eight to thirty.

Black men born in the 1960 s, particularly the late 1960 s (i.e., 1966 to 1970), fare better than black men born in the 1950s. About 75 percent of black men born in the late 1960s reported fewer than twenty-six weeks of nonwork from age twenty-eight to thirty. However, a significant percentage of black men born in the late 1960s still accumulated a year or more of nonwork. For instance, 19 percent of black men born from 1966 to 1970 accumulated a year or more of nonwork from age twenty-eight to thirty. This is worrisome, given that the men in this birth cohort were twenty-eight to thirty years old during the 1994-2000 economic expansion.

In Table 3.3, we report distributions of nonwork for all men, regardless of educational level. In Table 3.4, we report the same information for men 
Table 3.4. Distribution of Total Weeks of Nonwork: Ages $28-30$ by Year of Birth and Race, Men with High School Degree or Less

\begin{tabular}{llllrrr}
\hline & 0-12 Weeks & 13-25 Weeks & 26-52 Weeks & 1-2 Years & $>2$ Years & \# Obs \\
\hline & & \multicolumn{7}{c}{ White Men } \\
$1941-45$ & 69.21 & 18.20 & 5.05 & 6.88 & 0.65 & 142 \\
$1946-50$ & 55.36 & 19.09 & 12.98 & 10.55 & 2.03 & 206 \\
$1951-55$ & 43.49 & 25.43 & 16.84 & 8.42 & 5.82 & 276 \\
$1956-60$ & 59.37 & 19.60 & 12.52 & 6.97 & 1.54 & 258 \\
$1961-65$ & 54.98 & 20.79 & 12.65 & 7.13 & 4.44 & 207 \\
& & & & & & \\
$1941-45$ & 49.47 & 22.62 & 19.25 & 3.94 & 4.72 & 81 \\
$1946-50$ & 38.79 & 25.97 & 22.59 & 3.07 & 9.58 & 152 \\
$1951-55$ & 32.50 & 13.05 & 25.94 & 18.04 & 10.47 & 219 \\
$1956-60$ & 28.59 & 25.96 & 11.59 & 25.49 & 8.37 & 186 \\
$1961-65$ & 58.56 & 12.40 & 6.93 & 11.48 & 10.62 & 155 \\
\hline
\end{tabular}

Source: Authors' tabulations of Panel Study of Income Dynamics.

with a high school diploma or less. We omit the 1966-1970 birth cohort from Table 3.4 because of small sizes. Men with twelve or fewer years of schooling were somewhat more likely to accumulate substantial nonwork than men across all educational levels. Black-white differences in nonwork tend to be smaller in Table 3.4 than in Table 3.3 but are still significant.

\section{Discussion}

This chapter shows that men, particularly black men, found it more difficult to achieve stable employment in recent decades than in the past and fewer men achieved stable employment by their late twenties. Black men born in the 1950s, 1960s, and 1970s were more likely than those born in the late 1940s to be economically inactive in a given year and to report at least a year of nonwork during the three years between the ages of twenty-eight and thirty.

Why has stable employment become more elusive? One explanation currently in vogue highlights changing norms and attitudes toward work among the younger generation. For example, Flanagan et al. (2006) reported increases in the fraction of high school seniors saying that they "feel hesitant about taking a full-time job and becoming part of the 'adult' world." They also document a decline in seniors' interest in having a career, as well as the degree to which they define their self-concept in reference to a particular career. These differences in attitudes, the argument goes, may have resulted in young Americans opting to take more time wading into the labor market compared to earlier cohorts or to work less often altogether.
The analyses presented herein cast doubt on explanations that emphasize differences in attitudes and norms across cohorts. Decreases in work occurred within cohorts as well as across cohorts. Therefore, whereas young men are less likely to be working today than young men twenty years ago, older men still in their prime working years are less likely to be working today than they themselves were twenty years ago. This suggests that the changes in the structure of the economy over time discussed previously are reducing opportunities for stable employment for younger and older workers alike.

Another finding highlighted in this chapter is that race differences in men's disconnection from work have become significant. Most black and white men born in the 1940s were stably employed by their late twenties, and race differences in long-term nonwork were not significant for this cohort. In the 1940s birth cohort, 7 to 9 percent of white men and 9 to 11 percent of black men reported a year or more of nonwork between the ages of twenty-eight and thirty. In contrast, 28 percent of black men in the 1950 s birth cohort and 19 to 23 percent in the 1960s birth cohort reported a year or more of nonwork between the ages of twenty-eight and thirty, whereas only 5 to 10 percent of white men in these cohorts reported a year or more of nonwork between the same ages.

There is some good news in these results. Steady work from ages twentyeight to thirty is more common for both white and black men born in the late 1960s than for those born in the 1950s or 1940s, presumably due to the 1990s economic expansion. In the late 1960s birth cohort, 91 percent of white men and 75 percent of black men experienced fewer than twenty-six weeks of nonwork, and 77 percent of white men and 59 percent of black men experienced fewer than thirteen weeks of nonwork. Extensive nonwork from age twenty-eight to thirty is less common among white and black men in the late 1960 s cohort than among those in the late 1950 s cohort. However, despite this improvement, many black men born in the late 1960s remain disconnected from work in their late twenties and thirties. Almost one in five black men born in the late 1960 s experienced a year or more of nonwork from age twenty-eight to thirty, and roughly one in ten born in the late 1960s did not work a single week in the year they turned forty.

\section{Conclusion: Implications for Public Policy}

A small minority of white men and a large minority of black men are disconnected from work in their late twenties and thirties, long after leaving school. How can we increase men's connections to work? If, as we argue 
herein, the causes of the decline in stable employment are primarily related to the opportunity structure rather than changing norms and attitudes among the new generation, then policies should be targeted accordingly.

A standard answer is economic growth: "A rising tide lifts all boats." Economic growth clearly helps. During the 1990s expansion, rates of extensive male nonwork from the ages of twenty-eight to thirty fell by one third. However, economic growth alone cannot completely eliminate this disconnection from work. Although unemployment rates reached thirty-year lows in the 1990s expansion, 4 percent of white men and 19 percent of black men were out of work for a year or more between the ages of twenty-eight and thirty. A "rising tide" did not "lift all boats."

Another standard policy solution is education and training policies. There is currently widespread agreement among policy researchers and analysts that the U.S. economy has changed profoundly since the late 1970s. The number of manufacturing jobs that pay good wages to workers with no postsecondary schooling and that provide benefits and employment stability has dropped, and these jobs are not coming back. Schooling, cognitive skills, technological training, and communication slills have increasingly become prerequisites for jobs. Returns to schooling, cognitive skills, and early work experience rose throughout the 1980s and early 1990s and remain high. If men are to become connected to work, they need the skills to get jobs.

A mix of educational programs is required to meet the diverse needs of disconnected youth and youth at risk for disconnection. Given the high labor-market returns to associate's and bachelor's degrees, subsidizing the costs of postsecondary schooling by expanding the funding for Pell Grants is an important component of an education strategy. However, not all disconnected young men will choose this route (Cohen \& Besharov, 2004). In Reconnecting Disadvantaged Young Men, Edelman et al. (2006) reviewed and evaluated U.S. school and labor-market programs designed to improve young men's work skills and school-to-work transitions. They recommended the expansion of programs with proven track records and good cost-benefit ratios. The "proven" programs they recommended include mentoring and after-school programs (e.g., Big Brothers, Big Sisters), small high schools with career themes (e.g., Career Academics), and job-training programs for out-of-school youth (e.g., Job Corps). Edelman et al. (2006) also identified several initiatives as promising but not "proven" - apprenticeships, internships, and career and technical education in high schools and charter schools - and recommended that these initiatives be rigorously evaluated.
A third set of strategies is to "make work pay." A worker who works full time, year-round should have enough income after paying work expenses (e.g., transportation and child care) and taxes to live above the poverty level with health coverage. This is not the case for many low-skilled men in the United States.

How might one make work pay? Raising the minimum wage is one strategy, and the U.S. Congress has recently enacted a series of increases in the minimum wage to reach $\$ 7.25$ by July 2009 after it remained fixed at $\$ 5.15$ per hour between 1997 and 2007. Edelman et al. (2006) further proposed raising incomes of low-wage workers through wage subsidies, raising the Earned Income Tax Credit (EITC) for childless adults, and extending the EITC to noncustodial parents who pay child support. Milwaukee's New Hope Experiment provides another model. New Hope guaranteed workingpoor families subsidized health care, subsidized child care, and an income supplement that raised their income above the poverty line if a parent worked at least thirty hours per week.

Programs that focus on youth incarceration are another strategy that may help. In the 1990s, crime rates dropped in the United States but incarceration rates remained high. Edelman et al. (2006, p. 129) estimated that by age thirty-four, "perhaps up to 30 percent of black men will have been to prison." It is well documented that criminal records are barriers to employment. Edelman et al. (2006) recommended programs that divert youth from crime, reduce incarceration rates, increase the availability of education and training programs offered in prisons, and provide services and support for prisoners reentering the workforce.

A recent issue in U.S. policy debates about male nonwork is the extent to which garnishing the wages of noncustodial fathers for delinquent child support reduces male work effort in the legitimate labor market. Garnishing wages clearly reduces returns from work that are already low for low-skilled workers. This can have the unintended consequences of inducing some men to quit their job. These men may then fall even farther behind in childsupport payments, and they may become even more disconnected from work and from their children.

\section{REFERENCES}

Andersson, F., Holzer, H. J., \& Lane, J. (2003). Worker advancement in the low-wage labor market: The importance of "good jobs." Washington, DC: Brookings Institution, Center for Urban and Metropolitan Policy. 
Andersson, F., Holzer, H. J., \& Lane, J. I. (2006). Moving up or moving on: Employment and job stability among less educated workers. New York: Russell Sage Foundation.

Autor, D. H., \& Houseman, S. (2006). Temporary agency employment: A way out of poverty? In R. M. Blank, S. Danziger, \& R. Schoeni (Eds.), Working and poor: How economic and policy changes are affecting low-wage workers (pp. 312-337). Chicago: University of Chicago Press.

Autor, D. H., Levy, E., \& Murnane, R. J. (2002). Upstairs, downstairs: Computers and skills on two floors of a large bank. Industrial and Labor Relations Review, 55, 432 447.

Besharov, D. J. (Ed.) (1999). America's disconnected youth: Toward a preventive strategy. Washington, DC: CWLA Press.

Blank, R. (1998). Contingent work in a changing labor market. In R. Freeman \& P. Gottschalk (Eds.), Generating jobs: How to increase demand for less-skilled workers (pp. 258-294). New York: Russell Sage Foundation.

Bound, J., \& Freeman, R. (1992). What went wrong? The erosion of black relative wage gains. Quarterly Journal of Economics, 107(1), 201-232.

Bound, J., \& Holzer, H. (1993). Industrial shifts, skill levels, and the labor market for white and black males. Review of Economics and Statistics, 75(3), 387-394.

Bound, J., \& Johnson, G. (1992). Changes in the structure of wages in the 1980's: An evaluation of alternative explanations. American Economic Review, 82(3), 371392.

Cohen, M., \& Besharov, D. J. (2004). The important role of career and technical education: Implications for federal policy. College Park, MD: University of Maryland Welfare Reform Academy.

Corcoran, M., \& Matsudaira, J. (2005). Is it getting harder to get ahead? In R. A. Settersten, Jr., F. F. Furstenberg, Jr., \& R. G. Rumbaut (Eds.), On the frontier of adulthood Theory, research and public policy (pp. 356-395). Chicago: University of Chicago Press.

Danziger, S., \& Gottschalk, P. (1995). America unequal. New York: Russell Sage Foundation.

Devereux, P. (2003). Changes in male labor supply and wages. Industrial and Labor Relations Review, 56(3), 409-428.

Edelman, P., Holzer, H. J., \& Offner, P. (2006). Reconnecting disadvantaged young men Washington, DC: Urban Institute Press.

Flanagan, C. D., Osgood, W., Briddell, L., Wray, L., \& Syvertsen, A. (2006). The changing social contract at the transition to adulthood: Implications for individuals and the polity. Network on Transitions to Adulthood Research Network Working Paper.

Freeman, R., \& Holzer, H. (Eds.) (1986). The black youth employment crisis. Chicago: University of Chicago Press.

Freeman, R. \& Rodgers, W. (2000). Area economic conditions and the labor marke outcomes of young men in the 1990 s expansion. In R. Cherry \& W. Rodgers (Eds.) Prosperity for all? The economic boom and African Americans (pp. 50-87). New York Russell Sage Foundation.
Freeman, R., \& Waldfogel, J. (1998). Does child support enforcement policy affect male labor supply? In I. Garfinkel, S. McLanahan, D. Meyer, \& J. Seltzer (Eds.), Fathers under fire (pp. 94-127). New York: Russell Sage Foundation.

Freeman, R., \& Waldfogel, J. (2001). Dunning delinquent dads. Journal of Human Resources, 36(2), 207-225.

Grogger, J. (1998). Market wages and youth crime. Journal of Labor Economics, 16(4), 756-791.

Handel, M. (2003). Skills mismatch in the labor market. Annual Review of Sociology, 29, $135-165$.

Harding, D. (2003). Jean Valjean's dilemma: The management of ex-convict identity in the search for employment. Deviant Behavior, 24(6), 571-595.

Hollister, M. (2004). Does firm size matter anymore? The new economy and firm size wage effects. American Sociological Review, 69(5), 659-677.

Holzer, H. J., \& Offner, P. (2004). The puzzle of black male unemployment. The Public Interest, 154, 74-85.

Holzer, H. J., Offner, P., \& Sorensen, E. (2005). Declining employment among young black less-educated men: The role of incarceration and child support. Journal of Policy Analysis and Management, 24(2), 329-350.

Holzer, H. J., Raphael, S., \& Stoll, M. (2006). Will employers hire former offenders? In M. Pattillo, D. Weiman, \& B. Western (Eds.), Imprisoning America: The social effects of mass incarceration (pp. 205-246). New York: Russell Sage Foundation.

Juhn, C. (1992). The decline in male labor force participation: The role of declining market opportunities. Quarterly Journal of Economics, 107, 79-121.

Juhn, C. (2003). Labor market dropouts and trends in the wages of black and white men. Industrial and Labor Relations Review, 56(4), 643-662.

Juhn, C. , Murphy, K. M., \& Pierce, B. (1997). Wage inequality and the rise in returns to skill. Journal of Political Economy, 101(3), 410-442.

Juhn, C., \& Potter, S. (2006). Changes in labor force participation in the United States. Journal of Economic Perspectives, 20(3), 27-46.

Katz, L. F., \& Murphy, K. M. (1992). Changes in relative wages, 1963-1978: Supply and demand factors. Quarterly Journal of Economics, 107, 35-78.

Levy, F., \& Murnane, R.J. (1992). U.S. Earnings levels and earnings inequality: A review of recent trends and proposed explanations. Journal of Economic Literature, 30(3), 1333-1381.

Lobo, A. P., \& Salvo, J. J. (1998). Changing U.S. immigration law and the occupational selectivity of Asian immigrants. International Migration Review, 32, 737-760.

Mincy, R. B. (2006). Black males left behind. Washington, DC: Urban Institute Press.

Morris, M., \& Western, B. (1999). Inequality in earnings at the close of the twentieth century. Annual Review of Sociology, 25, 623-657.

Pager, D. (2003). The mark of a criminal record. American Journal of Sociology, 108(5), 937-975.

Pattillo, M., Weiman, D., \& Western, B. (Eds.) (2006). Imprisoning America: The social effects of mass incarceration. New York: Russell Sage Foundation.

Powell, W., \& Snellman, K. (2004). The knowledge economy. Annual Review of Sociology, 30, 199-204. 
Royalty, A. (1998). Job-to-job and job-to-non-employment turnover by gender and education level. Journal of Labor Economics, 16(2), 392-443.

Topel, R. H., \& Ward, M. P. (1992). Job mobility and the careers of young men. Quarterly Journal of Economics, 107(2), 439-479.

Western, B. (2006). Punishment and inequality in America. New York: Russell Sage Foundation.

Wilson, W. J. (1987). The truly disadvantaged: The inner city, the underclass and public policy. Chicago: University of Chicago Press.

Wilson, W. J. (1996). When work disappears: The world of the new urban poor. New York: Alfred Knopf. 